\title{
1,75
}

Mineral Resources of the Illinois-Kentucky Mining District

\author{
GEOLOGICAL SURVEY PROFESSIONALAPAPER 970
}





\section{Mineral Resources of the Illinois-Kentucky Mining District}

By DARRELL M. PINCKNEY

GEOLOGICAL SURVEY PROFESIONAL PAPER 970

Excellent possibilities exist for finding deposits of fluorspar, lead, zinc, silver, cadmium, rare earths, and niobium in Illinois and Kentucky

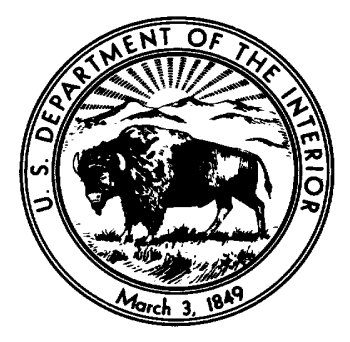

UNITED STATES GOVERNMENT PRINTING OFFICE, WASHINGTON : 1976 


\section{UNITED STATES DEPARTMENT OF THE INTERIOR}

THOMAS S. KLEPPE, Secretary

\section{GEOLOGICAL SURVEY}

V. E. McKelvey, Director

Pinckney, Darrell M.

Mineral resources of the Illinois-Kentucky mining district.

(Geological Survey Professional Paper 970)

Bibliography: p.

1. Mines and mineral resources-Illinois. 2. Minesand mineral resources-Kentucky.

I. Title. II. Series: United States Geological Survey Professional Paper 970.

TN24.13P56 553'.09769 76-8006

For sale by the Superintendent of Documents, U.S. Government Printing Office

Washington, D.C. 20402

Stock Number 024-001-02853-1 


\section{CONTENTS}

\begin{tabular}{|c|c|}
\hline Page & Page \\
\hline 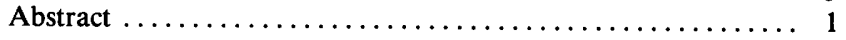 & Mineral deposits \\
\hline Introduction $\ldots \ldots \ldots \ldots \ldots \ldots \ldots \ldots \ldots \ldots \ldots \ldots \ldots$ & Minerals of the ore \\
\hline Production $\ldots \ldots \ldots \ldots \ldots \ldots \ldots \ldots \ldots \ldots \ldots$ & Structural types .... \\
\hline Composition of the ore $\ldots \ldots \ldots \ldots \ldots \ldots \ldots \ldots \ldots \ldots \ldots$ & Veins $\ldots \ldots \ldots \ldots \ldots \ldots \ldots \ldots \ldots \ldots \ldots \ldots$ \\
\hline Geologic setting $\ldots \ldots \ldots \ldots \ldots \ldots \ldots \ldots \ldots \ldots \ldots \ldots \ldots$ & Bedded deposits $\ldots \ldots \ldots \ldots \ldots \ldots \ldots \ldots \ldots \ldots \ldots$ \\
\hline 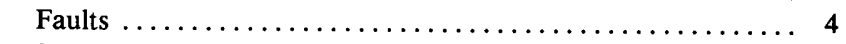 & Solution-slump breccias $\ldots \ldots \ldots \ldots \ldots \ldots \ldots \ldots \ldots \ldots$ \\
\hline Stratigraphy $\ldots \ldots \ldots \ldots \ldots \ldots \ldots \ldots \ldots \ldots$ & $\ldots \ldots \ldots \ldots \ldots \ldots \ldots$ \\
\hline Significance of the stratigraphic section in controlling ore & Deposits containing chiefly lead or zinc . \\
\hline 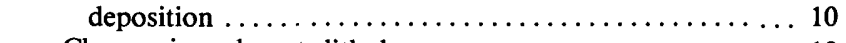 & $\ldots \ldots \ldots \ldots \ldots \ldots \ldots$ \\
\hline Changes in carbonate lithology $\ldots \ldots \ldots \ldots \ldots \ldots \ldots$ & 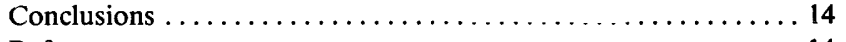 \\
\hline $\begin{array}{r}\text { Effect of shales on ore fluid } \ldots \ldots \ldots \ldots \ldots \ldots \ldots \ldots \ldots \ldots \ldots \ldots 10 \\
\text { Igneous rocks and diatremes } \ldots \ldots \ldots \ldots \ldots \ldots \ldots \ldots \ldots \ldots \ldots\end{array}$ & $\ldots \ldots \ldots \ldots \ldots \ldots \ldots \ldots \ldots \ldots$ \\
\hline
\end{tabular}

\section{ILLUSTRATIONS}

FIGURE 1. Index map showing location of the Illinois-Kentucky fluorspar region and nearby structural features $\ldots \ldots \ldots \ldots \ldots \ldots \ldots \ldots \ldots$

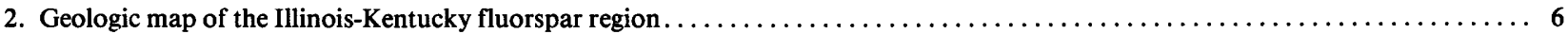

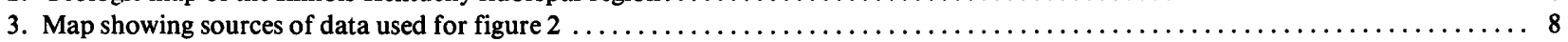

4. Stratigraphic column of the Mississippian formations in the Illinois-Kentucky fluorspar district $\ldots \ldots \ldots \ldots \ldots \ldots \ldots \ldots \ldots . \ldots 9$

5. Diagram of mineralized breccia of solution-slump origin in Hill mine, Cave in Rock district, Illinois . . . . . . . . . . . . .

\section{TABLES}

TABLE 1. Content of lead, zinc, and silver in four lots of selected ore from the Illinois-Kentucky mining district...................

2. Spectrographic analyses for selected elements in sphalerite, chalcopyrite, and galena from the Hill mine, Cave in Rock district, Illinois. 


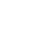




\title{
MINERAL RESOURCES OF THE ILLINOIS-KENTUCKY MINING DISTRICT
}

\author{
By DARRELl M. PINCKNEY
}

\begin{abstract}
The mineral deposits of the Illinois-Kentucky fluorspar district are the major source of domestic fluorspar; they also contain significant amounts of lead, zinc, barite, cadmium, and germanium, and some silver. Barite, strontium, and a small amount of copper are present, but mostly these are not recovered. The ores contain approximately 9.9 tons $(9 t)$ or more of lead and 55 tons $(50 \mathrm{t})$ or more of zinc per 1,102 tons $(1,000 \mathrm{t})$ of fluorite. The cadmium, germanium, and silver are contained chiefly in the sulfide minerals sphalerite and galena.

The major structural features of the region are a broad arch which trends northwestward, ending at Hicks dome, and a system of horsts and grabens that cross the arch and trend northeastward to eastward.

Mineral deposits belonging to four structural types are known: (1) veins, which are along normal faults related to the horsts and grabens; (2) bedded deposits, which are found in horsts; (3) solution-slump breccias, which extend downward below some bedded deposits; and (4) diatremes, which are related to the Hicks dome structure. The structural ore control of the first three types is the intersection of faults and other fissures with certain beds of Mississippian limestone. The mining area, about 540 square miles $\left(1,400 \mathrm{~km}^{2}\right)$, is nearly coextensive with the area of outcrop of these beds of limestone. The area of mineral potential is approximately doubled in size by projecting the favorable beds outwara rrom the mining area and downdip off the flanks and the end of the arch.

Many square miles of area having mineral potential within the structural framework defined here are unexplored. In addition, the mineral potential of the diatremes has been largely unrecognized. These facts, coupled with a substantial production from the area, indicate a large mineral potential in the region.
\end{abstract}

\section{INTRODUCTION}

The large mineralized area in southern Illinois and western Kentucky is loosely referred to as the Illinois-Kentucky fluorspar district because fluorspar has been the most important product of the region. The location of the area is shown in figure 1; the outline of the known mineralized area and the major geologic features of the region are shown in figure 2 . The known mineralized area covers about 540 square miles $\left(1,400 \mathrm{~km}^{2}\right)$ and contains many districts. The geology of the area has been studied for many years; general references include reports by Ulrich and Smith (1905), Bastin (1931), and Weller, Grogan, and Tippie (1952). Much of the geologic background for this report is included in reports by Trace (1974) and Hook (1974). The emphasis here, however, is

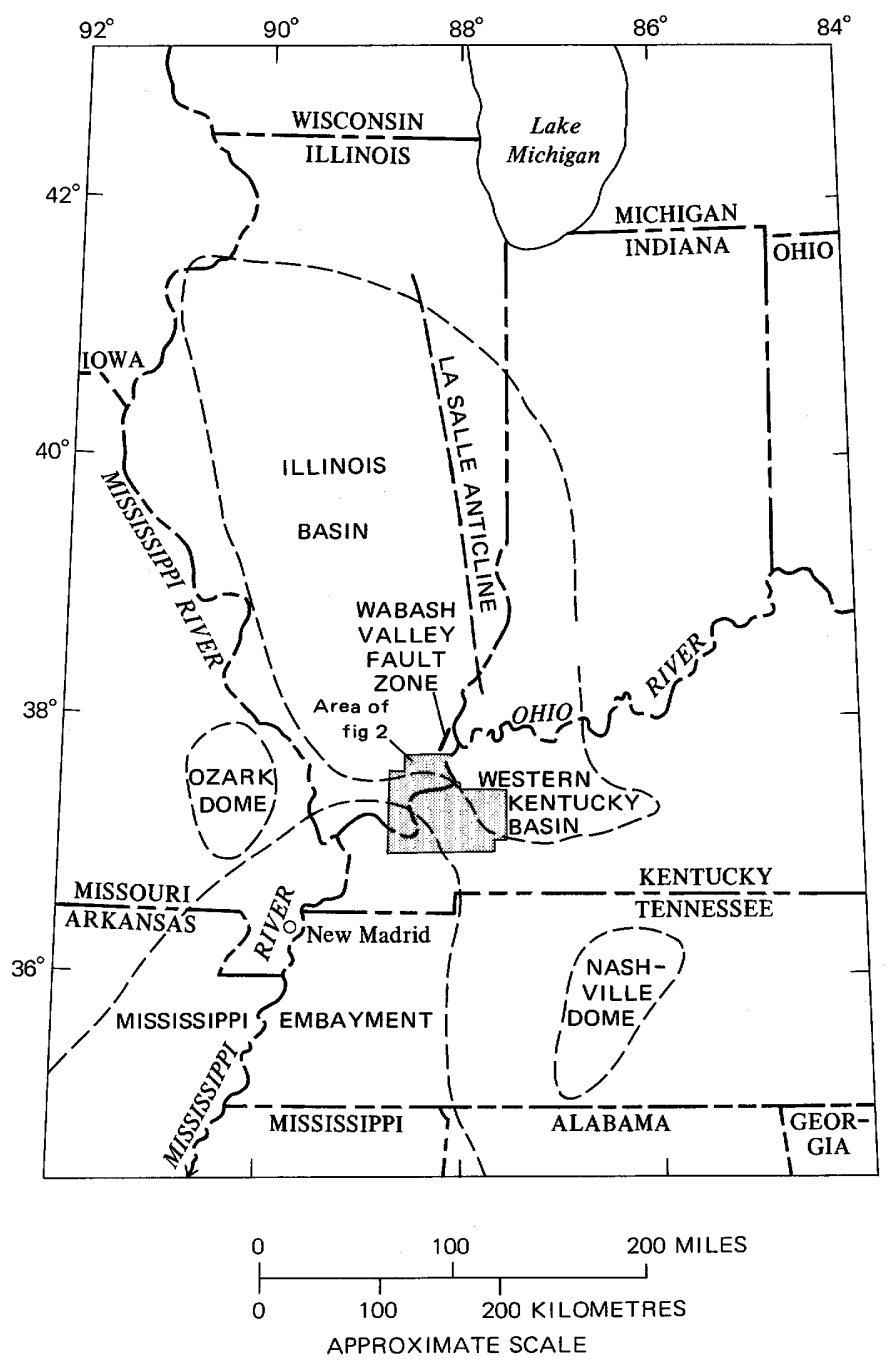

FIGURE 1.-Location of the Illinois-Kentucky fluorspar region and nearby structural features (dashed lines).

on pointing out the enormous potential remaining in both the known mineralized area and the surrounding region-in structurally controlled deposits that are localized by favorable stratigraphic horizons or by diatremes. 
The known mineral deposits occur as four major structural types: veins, bedded deposits, breccias of solution-slump origin, and diatremes. Deposits of all types contain fluorite, sphalerite, galena, chalcopyrite, and barite, and at least one diatreme also contains uranium-, thorium-, niobium-, and rare-earth-element-bearing minerals. Mining activity has concentrated on the vein and bedded types, and the solution-slump breccias and diatremes are not well known.

Nearly all the deposits of the region contain large amounts of fluorspar and differ significantly from other major deposits in the Mississippi valley, which are mined mainly for lead and zinc minerals. The lead and zinc now produced here are byproducts of fluorspar mining. Lead, however, was the first commodity mined (Ulrich and Smith, 1905, p. 16-21; Weller and others, 1952, p. 11), starting about 1835. In early mining, fluorite was considered to be a gangue mineral, but in the late 1800 's fluorite became valuable for its use as flux in the open-hearth furnaces of the steel plants in the upper part of the Ohio River valley. Sulfide minerals were detrimental to this use of the fluorspar ore, and ore free of sulfides was desired. Milling by selective flotation and by the sink-float process came into general use in the area in the late 1930's and early 1940's; lead and zinc have been recovered since then, and multicomponent ores are now mined.

The use of fluorspar has steadily increased for many years, and, because the Illinois-Kentucky mineralized area is the largest source of domestic fluorspar, production can be expected to increase correspondingly. Hence, the production of other commodities associated with fluoritechiefly lead, zinc, cadmium, and possibly barite-will also increase. Many deposits contain fairly large amounts of barite, some of which is now being recovered in conjunction with other products; until recently, problems of separating the barite from the other components of the ore discouraged significant production of barite.

The area has great potential for the discovery of additional deposits of fluorspar, lead, zinc, and barite, as well as other commodities (as discussed below); thus far, however, exploration has been inadequate to define this potential in terms of tons of the various commodities.

\section{PRODUCTION}

Since 1880 the area has yielded more than $9,500,000$ tons $(8,600,000 \mathrm{t})$ of fluorspar, 80 percent of the total U.S. production (Grogan and Bradbury, 1968, p. 373). Since 1939 it also has yielded more than 135,000 tons $(122,000 \mathrm{t})$ of zinc and more than 60,000 tons $(54,000 \mathrm{t})$ of lead. These amounts of lead and zinc constitute only a small part of the
U.S. production of these metals, but they increase the value of the ore significantly. Additionally, small amounts of silver and cadmium are recovered in refining the lead and zinc. The ores of the area furnish a significant amount of the cadmium produced in the United States.

Average values or grades of the fluorspar ores produced cannot be obtained from gross production figures, because the production figures are the sums of the tonnage of different products that have different contents of fluorite. In some years most of the fluorspar shipped was of metallurgical grade $\left(60-72.5\right.$ percent $\left.\mathrm{CaF}_{2}\right)$, and in other years most of the fluorspar shipped was of acid grade $(97$ percent $\mathrm{CaF}_{2}$ ). The value of the ores can be better estimated by analyzing some of the production data in relation to the grade of the fluorspar product.

\section{COMPOSITION OF THE ORE}

The ores differ in composition, but the quantitative differences are unknown because ore bodies are not systematically sampled. However, the variations are less important to mining operations extracting large amounts of ore than the average composition of the ore. An estimate of the average composition of the ore of the area has been obtained from statistics gathered by the U.S. Bureau of Mines and is presented in table 1.

The Bureau of Mines data were critically examined for this report, and by using those that show the grade of fluorspar, the absolute amounts of calcium flouride is calculated. The three major grades of fluorspar product are metallurgical $\left(60-72.5\right.$ percent $\left.\mathrm{CaF}_{2}\right)$, ceramic (85-96 percent $\mathrm{CaF}$ ), and acid (97 percent $\mathrm{CaF}_{2}$ ). Bradbury, Finger, and Major (1968) gave a good summary of industrial grades and uses of fluorspar. The values for each grade used to compute the total amounts of calcium fluoride are shown in table 1 . Only a few deposits have been mined chiefly for a product other than fluorspar. The veins at Rosiclare were first worked mainly for lead, several other deposits were mined chiefly for zinc, and one deposit produced mainly lead. Production data for such operations that produced a single product are not included in table 1 .

Table 1 shows the amounts of calcium fluoride, lead, zinc, and silver in large samples of ore from Illinois and Kentucky. In general, calcium fluoride is concentrated about $2-2 \frac{1}{2}$ times by milling in order to make the fluorspar products; thus, little concentration is required to turn large blocks of ore into salable products. In mining, $\mathrm{CaF}_{2}$ content of about 20 percent is usually the cutoff grade for ore, but lower grade material is extracted and 
T ABLE 1.-Content of lead, zinc, and silver in four lots of selected ore from the Illinois-Kentucky mining district

[All units are metric; tonnes $\times 1.1023=$ short tons; grams per tonne $\times 0.0202=$ troy ounces per short ton. Leaders $(\ldots)$ indicate insufficient data or not applicable]

\begin{tabular}{|c|c|c|c|c|c|c|c|c|c|}
\hline \multirow[b]{2}{*}{ Lot } & \multirow[b]{2}{*}{$\begin{array}{c}\text { Years } \\
\text { produced }\end{array}$} & \multirow[b]{2}{*}{ State } & \multirow[b]{2}{*}{$\begin{array}{l}\text { Crude ore } \\
\text { (tonnes) }\end{array}$} & \multirow[b]{2}{*}{$\begin{array}{c}\mathrm{Pb}^{1} \\
\text { (tonnes) }\end{array}$} & \multirow[b]{2}{*}{$\begin{array}{c}\mathrm{Zn}^{1} \\
\text { (tonnes) }\end{array}$} & \multirow[b]{2}{*}{$\begin{array}{c}\mathrm{Ag}^{2} \\
\text { (grams) }\end{array}$} & \multicolumn{3}{|c|}{ Metals in crude ore } \\
\hline & & & & & & & $\begin{array}{c}\mathrm{Pb} \\
\text { (percent) }\end{array}$ & $\begin{array}{c}\mathrm{Zn} \\
\text { (percent) }\end{array}$ & $\begin{array}{c}\mathbf{A g} \\
\text { (g/tonne) }\end{array}$ \\
\hline \multirow{3}{*}{$\begin{array}{l}1 \\
2\end{array}$} & $1953-56$ & Ill. & $1,090,815$ & 7,127 & 25,098 & $2,097,992$ & 0.65 & 2.3 & 1.9 \\
\hline & $1957-59$ & Ill. & 596,614 & 2,158 & 12,222 & $\ldots$ & .36 & 2.0 & $\cdots$ \\
\hline & \multicolumn{2}{|c|}{ Average metal content } & $\cdots$ & $\cdots$ & re $>$ & 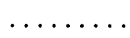 & 0.51 & 2.2 & $\cdots$ \\
\hline \multirow{3}{*}{$\begin{array}{l}3 \\
4\end{array}$} & $1953-55$ & Ky. & 57,557 & 47 & 452 & & 0.081 & 0.78 & $\cdots$ \\
\hline & $1956-59$ & Ky. & 57,671 & 675 & 1,520 & 33,872 & 1.2 & 2.7 & 0.59 \\
\hline & \multicolumn{2}{|c|}{ Average metal content } & & & & & 0.64 & 1.7 & \\
\hline
\end{tabular}

\begin{tabular}{|c|c|c|c|c|c|c|c|c|c|c|}
\hline \multicolumn{11}{|c|}{ Additional data on lots 2 and 4} \\
\hline & \multicolumn{3}{|c|}{ Fluorspar (tonnes) ${ }^{3}$} & \multicolumn{4}{|c|}{$\mathrm{CaF}_{2}$ (tonnes) $^{3}$} & \multicolumn{3}{|c|}{ Ratio of metal to $\mathrm{CaF}_{2}$} \\
\hline Lot & $\mathbf{M}$ & A & $\mathrm{C}$ & $\mathbf{M}$ & $\mathbf{A}$ & $\mathrm{C}$ & Total & $\mathbf{P b}$ & $\mathrm{Zn}$ & $\mathrm{Ag}$ \\
\hline 2 & 31,507 & 180,534 & 39,959 & 18,903 & 175,118 & 37,163 & 231,184 & 0.0093 & 0.053 & \\
\hline 4 & 9,900 & 16,712 & 4,891 & 5,940 & 16,210 & 4,548 & 26,698 & .025 & .057 & $1.3 \times 10^{-6}$ \\
\hline
\end{tabular}

\footnotetext{
1 The amounts of $\mathrm{Pb}$ and $\mathrm{Zn}$ shown are the amounts reported as recovered. The recovered metal is about 95 percent of the total in the concentrates.

${ }^{2}$ The amounts of $\mathrm{Ag}$ shown are the totals reported from wet assay data of concentrates. The amounts reported as actually
} recovered are approximately 12 percent of these totals.

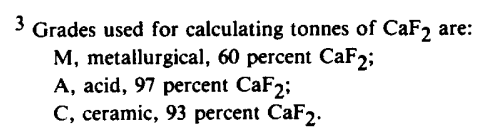

blended with high-grade ore as long as the desired millfeed is maintained.

The crude ore listed in table 1 contains about 0.5 percent lead and about 2 percent zinc. Thus, the deposits of the area tend to be near the marginal limit for lead-zinc deposits and probably could not be mined economically on a sustained basis for lead and zinc alone. The crude ore from Illinois contained slightly more zinc and slightly less lead than that from Kentucky. However, the production data used for table 1 may reflect how the ore was mined and was concentrated, and minor differences in the nature of the crude ore may not be significant. The ratios of lead and zinc to calcium fluoride (table 1) probably show the character of the ore more accurately; the $\mathrm{Zn}: \mathrm{CaF}_{2}$ ratio for Kentucky ore is nearly three times as high as that for Illinois. The differences in the $\mathrm{Pb}: \mathrm{CaF}_{2}$ ratios might reflect different types of deposits; most of the ore from Illinois was from bedded deposits, and most of the ore from Kentucky was from veins.

Some silver has been recovered from sulfide concentrates from both Illinois and Kentucky. Silver may occur throughout the area, but for some years no recovery was reported. Table 2 shows that silver occurs in sphalerite, galena, and chalcopyrite in amounts comparable to those reported in the production data. Therefore, the silver of the district is fully extracted by the mining and milling techniques already in use and additional recovery of silver will depend upon smelting processes.

The area is a source of cadmium, which is recovered from the zinc concentrates during smelting. The cadmium is chiefly in the sphalerite, which also contains most of the

T ABLE 2.-Spectrographic analyses (in percent) for selected elements in sphalerite ( $\mathrm{S})$, chalcopyrite (C.p), and galena (Gl) from the Hill mine, Cave in Rock district, Illinois

[M, major constituent. Analyst, Harriet G. Neiman, U.S. Geol. Survey]

\begin{tabular}{cccccccc}
\hline $\begin{array}{c}\text { Sample } \\
\text { No. }\end{array}$ & Mineral & Fe & Ag & Cd & Cr & Cu & Ge \\
\hline $902 \ldots$ & Sl & 0.7 & 0.0 & 0.5 & 0.0003 & 0.07 & 0.03 \\
$903 \ldots$ & Sl & 1.5 & .002 & 1.5 & .0001 & .07 & .02 \\
$904 \ldots$ & Cp & M & .991 & .01 & .003 & M & .01 \\
$905 \ldots$ & Gl & .03 & .0007 & .0 & .0 & .02 & .0 \\
$906 \ldots$ & Gl & .015 & .0005 & .0 & .001 & .005 & .0 \\
$907 \ldots$ & Gl & .015 & .01 & .0 & .0002 & .003 & .0 \\
\hline
\end{tabular}


germanium in the district; only a small amount of cadmium is in chalcopyrite (table 2), and no other cadmium-bearing minerals are known in the primary ore. Thus, only normal mining operations are needed to extract all the recoverable cadmium from the ground.

\section{GEOLOGIC SETTING}

The mineralized area was formerly part of the Illinois-Indiana-Kentucky depositional basin. This basin is on the North American craton west of the Appalachian trough and was the site of deposition of more than 13,000 feet $(4,000 \mathrm{~m}$ ) of sediments during Paleozoic times (Bayley and Muehlberger, 1968). During the later part of Mississippian time, the types of sedimentation in the area changed from deeper marine of the continental shelf to near-shore marine. The change continued into Pennsylvanian time, and the basin received coastal-type sediments that contain large amounts of coal. By Late Pennsylvanian time the basin seems to have been completely filled. During Mississippian time, the northern and central parts of the basin were partly separated into eastern and western basins by the rise of the La Salle anticline belt. Later, Hicks dome (fig. 2) and the area to the southeast rose, thereby almost completing the separation between the Illinois basin on the west and Western Kentucky basin on the east.

The major part of the uplift in the south occurred after the deposition of the Pennsylvanian coal beds. However, the uplift may have started as early as Early Pennsylvanian; Desborough (1961) found beds of the Lower Pennsylvanian Caseyville Formation that were faulted and then were covered by slightly younger beds of the same formation. The map pattern of the MississippianPennsylvanian contact around the mineralized area (fig. 2) shows that the regional structure is a broad, low arch on the south edge of the Illinois and Western Kentucky basins. Northward from the Nashville dome and eastward from the Ozark dome (fig. 1), the strata dip gently toward the Illinois and Western Kentucky basins, and the arch is scarcely more than a slight reversal in the dip of these strata.

The north-northwest trend of the arch is apparent in figure 2 by the distribution of the Lower Mississippian formations. Hicks dome is at the northwest end of the arch; the southeastward extent of the arch is not known, for it is covered by sediments of the Mississippi embayment. The arch is bounded on the north and east by synclines. North of Hicks dome the beds dip steeply into the Eagle Valley syncline, rise up into an anticline a little farther north, and finally dip downward into the Illinois basin. Eastward, in Kentucky, along the northeast side of the area, the beds dip gently northeastward into the eastern extension of the Eagle Valley syncline and the Western
Kentucky basin. Regional dips are less apparent on the southwest side of the arch. In the area north of the edge of the Cretaceous and Tertiary formations and west of the Ohio River, the regional dip is northward into the Illinois basin. South of Carrsville, Ky., between the Ohio River and the central part of the arch, the regional dip is obscure because of faults.

The rocks of the arch are broken into many horsts and grabens, which are separated by normal faults. The horsts are broad, broken by faults, and poorly defined; they are separated from the grabens by complicated fault zones that include many branches and step faults. (See, for example, Moodie and McGrain, 1974, figs. 7, 8, 9.) The grabens are narrower and less faulted, and they are seen easily on the geologic maps of the region.

Eleven grabens have been well defined by geologic mapping, and they are shown in figure 2; Hook (1974) also presents a map showing the grabens that is similar to figure 2 , but of a smaller area. The two maps are independent compilations; the names used here to designate the grabens either are well established by local usage or are chosen from the names of town within the structure. The grabens tend to die out to the east or northeast in the Pennsylvanian sedimentary rocks, and they are poorly known to the southwest where they are partly covered by the Cretaceous and Tertiary sediments. Two grabens, the Sheridan and the Marion, converge into a complex fault zone near the great bend of the Cumberland River. The convergence appears to be along the projection of the Tabb fault zone. The Dawson Springs graben is well defined in its eastern part but is more complex to the west. Near the southwest end the structure contains several raised blocks between the bounding faults. East of the Tabb fault zone the Dawson Springs graben contains Pennsylvanian rocks and is bounded on both sides by Mississippian rocks. In contrast, to the southwest of the Tabb fault zone, the graben contains Mississippian rocks, some of which are older and some of which are younger than the Mississippian rocks of the adjacent horsts. The oldest rocks are toward the southwest. Perhaps the structure has been raised toward the southwest and tilted toward the northeast. However, according to R. D. Trace (U.S. Geological Survey, oral commun., 1974) identification of the formations at the surface in the southwestern part of the Dawson Springs graben is difficult.

\section{FAULTS}

The fault structure of the region is dominated by normal faults that define the regional framework of horsts and grabens. Faults related to other structures include radial and concentric faults around Hicks dome, northwardtrending faults in blocks, between the grabens, the Shawneetown fault zone, and the Tabb fault zone. 
Normal faults having a northeasterly to easterly trend are predominant. Most of the northeast-trending faults are part of fault zones that bound grabens and horsts. These fault zones extend southwestward under the sediments of the Mississippi embayment and may be part of the New Madrid fault zone. To the northeast they are less well known in the Pennsylvanian sedimentary rocks of the Illinois basin; much of the area north and northeast of Hicks dome is covered with either alluvium or glacial till. Some of the northeast-trending faults probably extend into the Wabash Valley fault zone. Along their northeasterly courses, many of the faults tend to swing to the east. This change in strike is very strong in the eastern part of the region. A few faults trend northward; these are mostly near Rosiclare and are in the horsts between the grabens. Their relation to other structures is not clear. Vertical movement on the faults that bound the grabens is only about 650 feet $(200 \mathrm{~m})$ or less in most places, and the maximum displacement known is less than 3,000 feet $(900$ m) (Trace, 1974, p. 67-69).

The radial faults are known only at the northwest end of Hicks dome. They lie along both sides of the axis of the dome and project inward to a small area that is very close to the center of the dome. A few of the radial faults bound small grabens. The radial faults resulted from stretching of the rocks around the end of the rising dome. Concentric faults surround the northwest end of the dome for almost $180^{\circ}$ of arc. They are normal faults downthrown on the inside toward the center of the dome. Movement along them resulted from collapse of the dome.

The Shawneetown fault zone passes through the Western Kentucky basin, where it is called the Rough Creek fault zone, and through the Eagle Valley syncline, where it occupies the axial part of the syncline. Both structures bend around the northwest side of Hicks dome. The syncline dies out in a complex zone of faults that extends several miles to the southwest as the northwest side of the Dixon Springs graben. Heyl and Brock (1961) and Grogan and Bradbury $(1968$, p. 376) referred to the Shawneetown fault zone as a high-angle thrust fault, but they gave no evidence. From the original work of Butts (1925, pl. 1) and Baxter, Desborough, and Shaw (1967, pl. 1), one can conclude only that the fault zone dips at a high angle, and on cross sections Butts (1925) showed it as being vertical. Southward dip and thrusting seem to be conjectural. The only evidence for reverse movement apparently is a group of relatively upthrown blocks on the north and west sides of Hicks dome. However, these blocks are within the fault zone, and during the collapse of Hicks dome they probably failed to move downward as much as the adjacent blocks. No outliers have been found. This author concludes that thrusting probably did not occur to any significant extent and that movement on the Shawneetown fault zone is normal rather than reverse.
The Tabb fault zone is an arcuate complex zone of faults extending more than 35 miles $(56 \mathrm{~km})$. The extent of the zone to the southeast is not fully known. The fault zone intersects three grabens; downthrow is on the north, and the western part of the fault zone clearly separates younger Mississippian rocks on the north side of the fault from older rocks on the south side of the fault. The vertical displacement may diminish to the south.

\section{STRATIGRAPHY}

The Illinois-Kentucky fluorspar region is underlain by a thick section of Paleozoic strata. The oldest formation exposed, the Hunton Limestone of Silurian and Devonian age, crops out in the central part of Hicks dome. Nearly all the central part of the region is underlain by Mississippian formations at the surface, and these formations are bordered to the east and north by Pennsylvanian formations. The extreme southern part of the region is partly covered by a veneer of unconsolidated sediments of Cretaceous and Tertiary age. These sediments are the north edge of the great prism of sediments in the Mississippi embayment, and they overlie an unconformity that cuts across the Mississippian rocks.

The exposed rocks in the area of figure 2 are more than 5,800 feet $(1,700 \mathrm{~m})$ thick, yet almost all the ore has come from a relatively thin section of Mississippian rocks that comprises the upper part of the Meramecian and lower part of the Chesterian Series. A generalized section of Mississippian formations is shown in figure 4.

During the Mississippian Period, a major change occurred in the conditions of sedimentation, from deep marine to nearshore marine. The Lower Mississippian rocks, below the productive section, are chiefly very fine grained limestones which contain, in some places, chert. They represent a deepwater marine environment. The productive section consists chiefly of nearly pure limestone composed of well-sorted clastic oolites and fossil fragments. This part of the section also contains some well-sorted and fine-grained sandstone and a minor amount of shale. A large proportion of the upper part of the Mississippian section above the productive beds is sandstone and shale interspersed with limestone. The productive section also changes gradually upward in lithology and composition. The lowest part is chiefly dark-gray, fine-grained, and impure limestone of the lower part of the St. Louis Limestone (fig. 4). This grades upward into limestone that is cherty in part, medium to light gray, and generally fine grained, but that contains oolitic beds.

The St. Louis Limestone is overlain by the Ste. Genevieve Limestone, which is divided into the Fredonia Limestone, Rosiclare Sandstone, and Levias Limestone Members. The Fredonia Limestone Member is much 


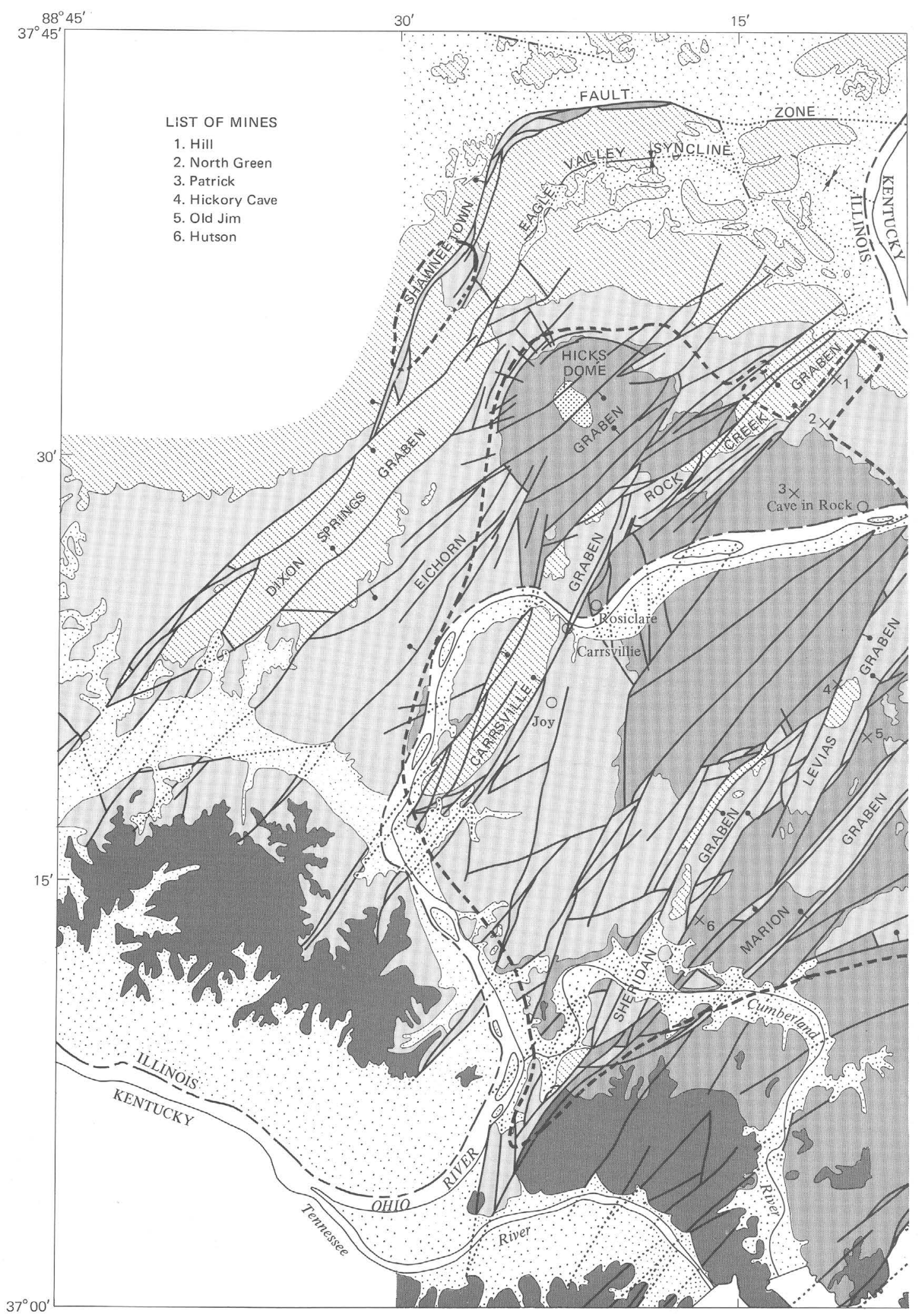

FIGURE 2.-Geologic map of the Illinois-Kentucky 
EXPLANATION

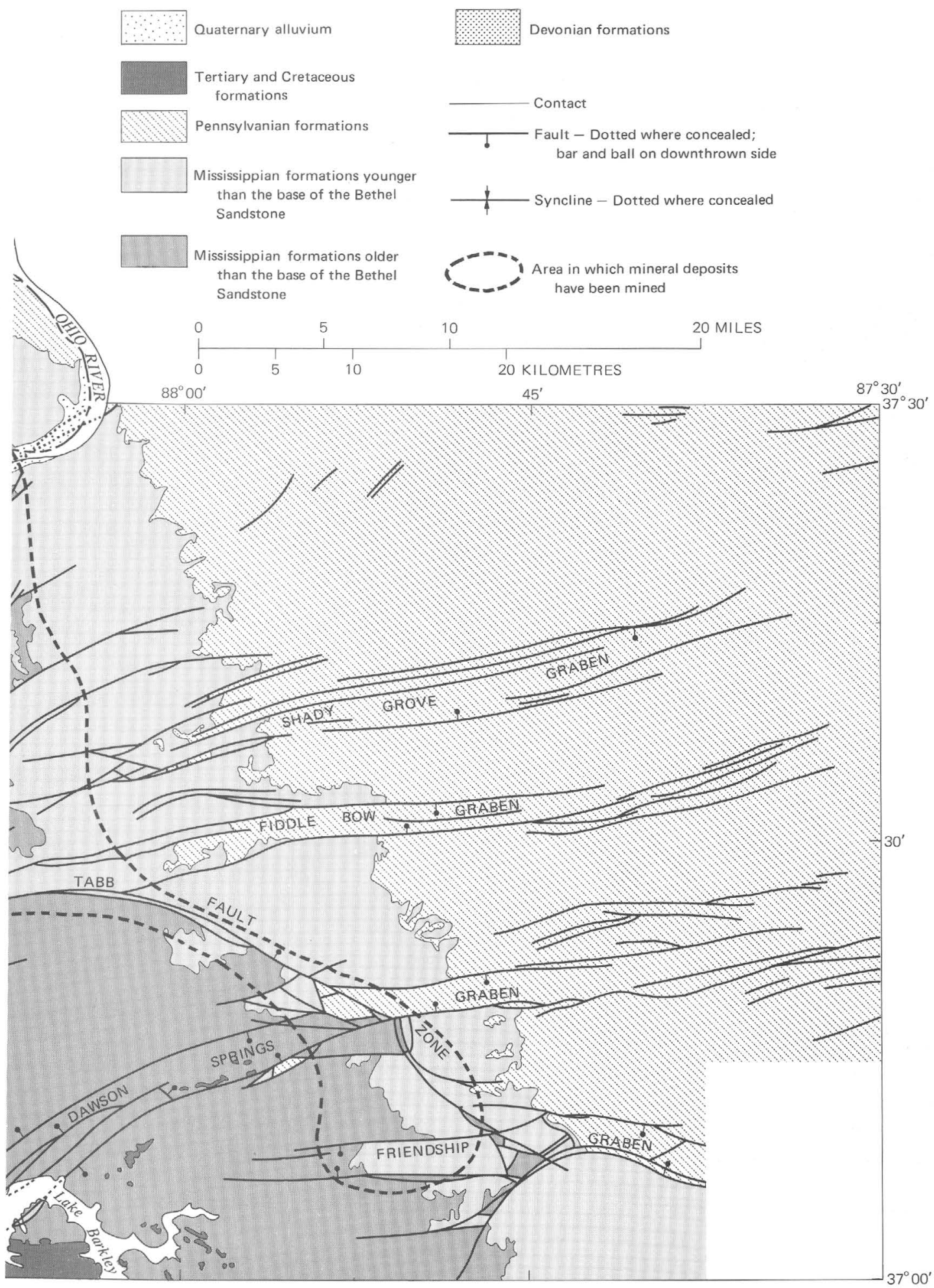

fluorspar region. Sources of data are shown in figure 3 . 


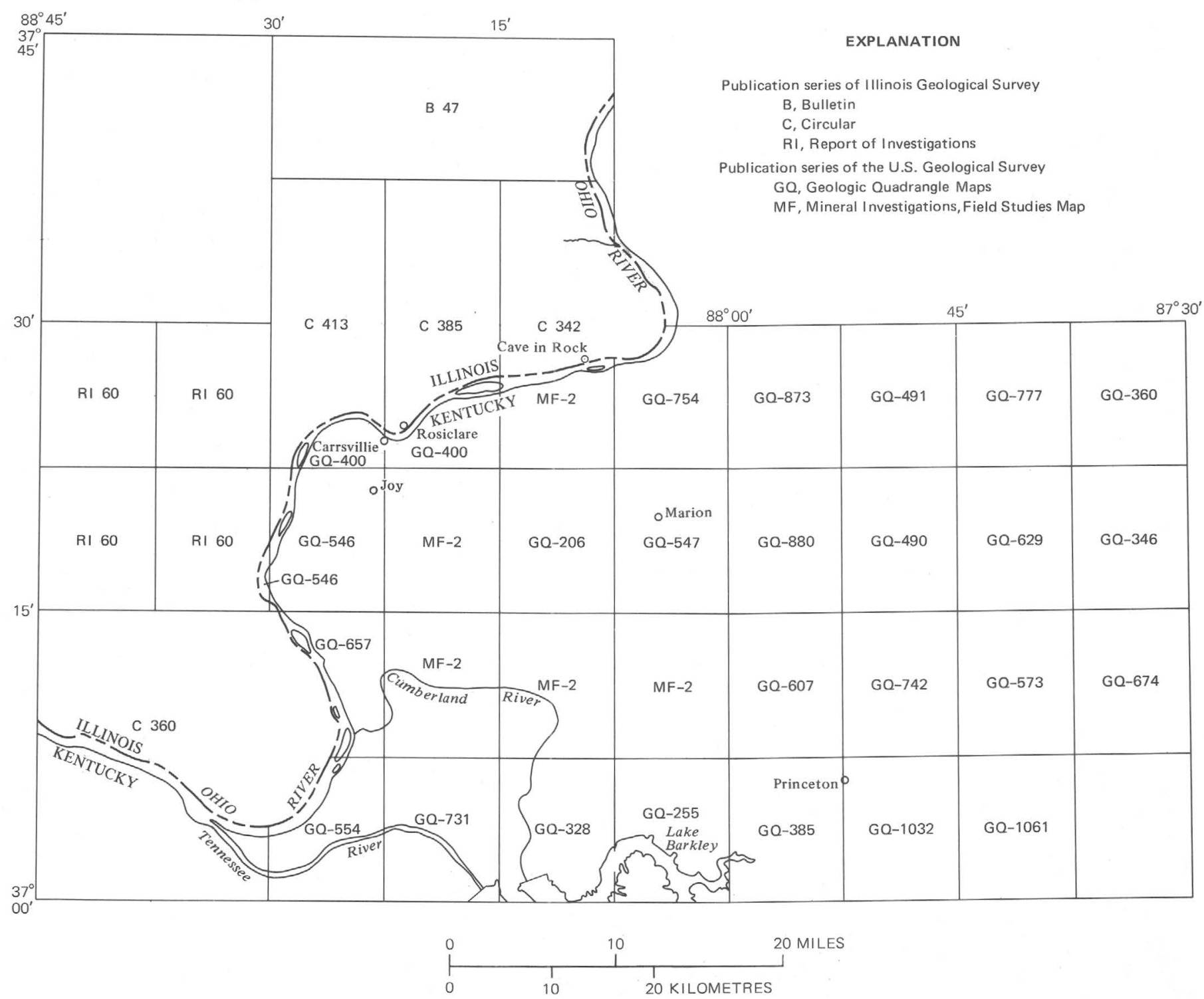

F IGURE 3.-Sources of data published by Illinois Geological Survey and U.S. Geological Survey used in compilation of figure 2.

lighter in color than the St. Louis Limestone. Limestone in the Fredonia tends to be oolitic, contains numerous fossil fragments, and is nearly pure calcium carbonate that contains little chert. The Fredonia contains scattered thin and discontinuous beds of marine shale. In some places, especially in the Cave in Rock district, Illinois, it also contains a thin and fine-grained sandstone, an economic unit known as the Sub-Rosiclare ore zone. This sandstone is commonly very calcareous, crossbedded, and diiscontinuous. It changes facies from calcareous sandstone to sandy and oolitic limestone within a short distance, but it can be identified by a distinctive sequence of beds (Pinckney and Rye, 1972). Its stratigraphic position has been stated (Brecke, 1962) as ranging from 40 to 60 feet $(12-18 \mathrm{~m})$ below the base of the Rosiclare Sandstone Member. The Fredonia Limestone Member beneath the Sub-Rosiclare ore zone is characterized by large oolites, fossil fragments, and current bedding, suggestive of a bank of reworked lime in shallow water. The features of the overlying Sub-Rosiclare ore zone are suggestive of a shifting channel that extended across the bank. The source of the sand was probably to the northeast in the Precambrian terrane of the North American craton (Pinckney and Rye, 1972).

The Fredonia Limestone Member above the distinctive sequence of the Sub-Rosiclare ore zone is similar to that 


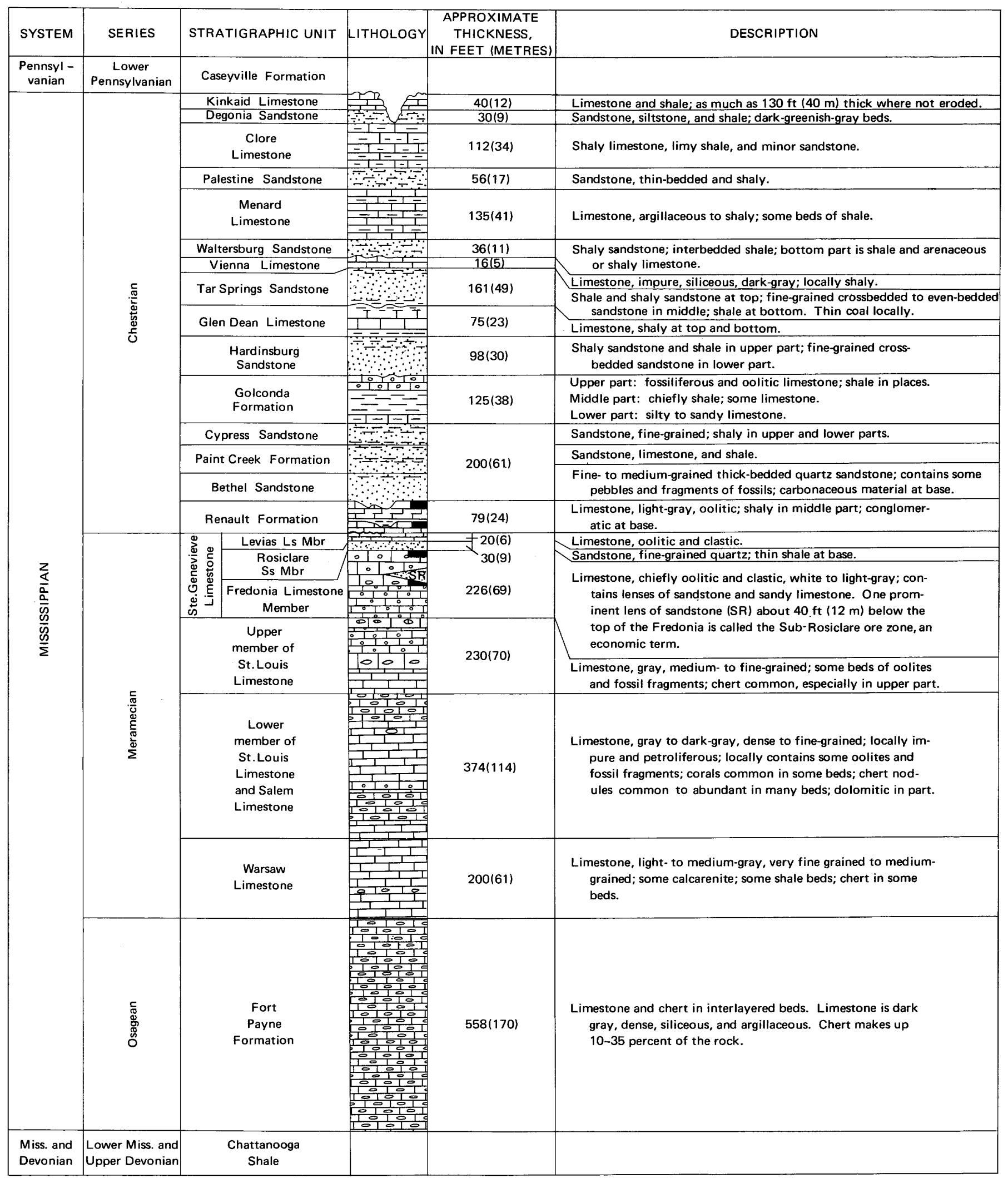

F IGURE 4.-The Mississippian formations in the Illlinois-Kentucky fluorspar district. The chief ore-bearing beds are shown by solid bar. 
beneath it, consisting dominantly of oolites and fossil fragments, except that it contains beds of sandy limestone.

The Rosiclare Sandstone Member is in the upper part of the Ste. Genevieve Limestone. Fine grained, calcareous, and locally shaly, the Rosiclare ranges in thickness from about 20 to 40 feet $(6-12 \mathrm{~m})$. It represents the first major influx of clastic material, which was spread in a thin blanket across the entire region. In places the Rosiclare contains lenses of limestone or shale, and a thin shale is commonly found at its base.

The Levias Limestone Member is the uppermost part of the Ste. Genevieve Limestone and the Meramecian Series. It is medium to light gray, fairly thick bedded, and oolitic, and it contains some thin shale partings and many fragments of fossils. The Levias ranges in thickness from about 10 to 35 feet $(3-11 \mathrm{~m})$, and in places it contains a basal conglomerate.

The Renault Formation is the basal formation of the Chesterian Series and overlies the Ste. Genevieve Limestone. It consists dominantly of limestone andd shale and ranges in thickness from about 70 to 125 feet (21-38 $\mathrm{m})$. Some of the limestone is oolitic and crossbedded. The limestone is not as pure as that of the Ste. Genevieve, and some is carbonaceous and locally contains pyrite. In general, the lower part of the formation is limestone or shaly limestone, the middle part is shale, and the upper part is fairly pure limestone. In many places the Renault Formation rests unconformably on the Levias Limestone Member.

The Bethel Sandstone, though dominantly sandstone, varies in lithology across the region. To the south and southeast, the formation thins and contains siltstone and shale. To the north, especially in Illinois, it is thicker and consists largely of fine to medium sand but also contains coarse and angular grains, and even pebbles. In many places the Bethel is unconformable upon the Renault, and to the southeast the Bethel has been found, probably as a channel deposit, resting on Ste. Genevieve Limestone (Trace and Kehn, 1968). The Bethel probably represents a Mississippian delta; bottomset and foreset beds are present in some of the mines of the Cave in Rock district.

\section{SIGNIFICANCE OF THE STRATIGRAPHIC SECTION IN CONTROLLING ORE DEPOSITION}

\section{CHANGES IN CARBONATE LITHOLOGY}

Carbonate deposition that formed marine limestone, dominantly, throughout much of Mississippian time ended with deposition of the deltaic sandstone of the Bethel Sandstone. Marine limestone does occur higher in the section, but it is interspersed with thick beds of clastics, chiefly shale and sandstone. Prior to the incursion of the clastic sediments, the depositional environment of the lower part of the St. Louis Limestone was a marine shelf in fairly deep water. Gradually, the environment shifted to shallow-water facies, especially during deposition of the Ste. Genevieve and Renault Formations.

The shallow nearshore environment of deposition of the Ste. Genevieve Limestone and Chesterian Series is briefly described by Fraunfelter and Utgaard (1973, p. $35-37)$. They report the oolitic limestone of the Ste. Genevieve Formation as representing deposition on a shallow marine shelf, similar to the one currently existing in part of the Bahama Islands region. Klein (1974, table 1) suggests that the Aux Vases Sandstone, which is represented by the Rosiclare Sandstone Member in the mining area, was deposited in water that was only about 8 feet $(2.5 \mathrm{~m})$ deep.

The clastic and oolitic nature of the limestone of the productive section indicates that these rocks were very porous at the time of deposition and burial. The author believes that some of the rocks of the productive section were still very porous when mineralization occurred. Indeed, some zones in the same part of the section are still very porous and permeable. For example, the McClosky sand zones, which are good producers of oil in the Illinois and Western Kentucky basins, consist - of uncemented oolites and are highly permeable. High permeability in some of the carbonate rocks probably influenced mineral deposition strongly.

\section{EFFECT OF SHALES ON ORE FLUIDS}

Above the Bethel Sandstone the stratigraphic section contains much shale, and, in general, the amount of shale increases upward. The shales are incompetent, and many of them deformed plastically during and after faulting. Many faults, not shown on the areal maps, were important channels for the solutions that formed the bedded mineral deposits, even though the vertical displacement on these faults is only a few feet or less. These faults tend to terminate upward within beds of shale or shaly limestones, the movement along the faults having been taken up within the plastic shale. In many other faults that continue through a shale bed, shale squeezed into the fault and closed it to the further upward movement of the ore solutions. The effect of the shales was to seal, or partly seal, many fissures above the Bethel Sandstone and to restrict the formation of fissures through the shales. This effect prevented ore-bearing fluids from reaching the limestones of the Chesterian Series. Instead, a large part of the fluid probably moved through the porous beds of the productive section, which is below the Bethel Sandstone.

\section{IGNEOUS ROCKS AND DIATREMES}

The region contains many small bodies of igneous rocks and several diatremes. These have aroused much speculation about their relation to the origins of both the structure of the region and the mineral deposits. Clegg and Bradbury (1956) showed nearly 80 occurrences of intrusive 
rock in southern Illinois, and possibly as many exist in Kentucky, but no compilation of the intrusive rocks in Kentucky has been made. The exposed igneous rocks form dikes, small plugs, and a few thin sills. The igneous rocks are highly altered; the freshest specimens are mica peridotites (Clegg and Bradbury, 1956).

An aeromagnetic study (McGinnis and Bradbury, 1964) showed a magnetic high centered about 5 miles $(8 \mathrm{~km})$ northeast of the center of Hicks dome. The magnetic pattern is consistent with a model of a body of basic igneous rock at a depth of between 11,000 and 15,000 feet $(3,350-4,570 \mathrm{~m})$ and having a horizontal diameter of about 12 miles $(19 \mathrm{~km})$. The depth of the basement northeast of Hicks dome (Bayley and Muehlberger, 1968) is approximately $12,000-13,000$ feet $(3,700-4,000 \mathrm{~m})$. The edge of the body of igneous rocks may pass under Hicks dome, but McGinnis and Bradbury (1964) concluded that the structure of Hicks dome is not due to intrusion of a laccolith centered under the apex of the dome.

The known diatremes are in the vicinity of Hicks dome. They are known to be as much as 800 feet $(250 \mathrm{~m})$ across and consist chiefly of fragments of sedimentary rocks in a matrix of finely ground rocks and minerals. Some contain fragments of peridotite. The diatremes are poorly known because of poor exposures. Brown, Emery, and Meyer (1954) described what is surely a diatreme from data of an exploratory oil well, Henry Hamp, Jr., 1, which was drilled in the center of Hicks Dome. The Hamp well encountered breccia from a depth of 1,815 feet $(533 \mathrm{~m})$ to the bottom of the hole at 2,944 feet $(897 \mathrm{~m}$ ). Trenches (not described by Brown and others, 1954) several hundred feet west of the drill hole expose beds that are broken and are jumbled. These facts suggest either that the diatremes may be considerably larger than indicated on the geologic maps by Baxter and Desborough (1965) and Baxter, Desborough, and Shaw (1967) or that the diatremes are surrounded by broken and deformed beds.

\section{MINERAL DEPOSITS}

\section{MINERALS OF THE ORE}

The chief minerals of the ore are fluorite, sphalerite, galena, and calcite. Barite, strontianite, and quartz are abundant in some deposits. Chalcopyrite is present in nearly all the deposits, but only in small amounts. Marcasite and pyrite have been reported from a few places. Smithsonite was abundant at the surface in some deposits, since mined out.

Fluorite, sphalerite, and galena are recovered in nearly all the mining operations. Some barite is being recovered now by one company. In most deposits, however, barite is treated as a gangue mineral. A large amount of limestone is extracted with the ore; some is sold as road metal.

\section{STRUCTURAL TYPES}

The deposits are of four major structural types: (1) veins and associated replacement bodies, (2) bedded deposits, (3) solution-slump breccias, and (4) diatremes.

\section{VEINS}

Veins occur throughout the area and have been worked for more than 100 years. The veins occupy faults, chiefly those bounding grabens and horsts. The veins are largely open-space fillings, but replacement of the wallrocks and fragments of rock commonly occurred. The amount of stratigraphic displacement on the faults seems to have been unimportant as an ore control, though it is often mentioned as an influencing factor. The type of wallrocks in the faults appears to be an important ore control. The most productive veins have at least one wall consisting of clastic limestones, as described previously, regardless of the amount of displacement on the fault.

The veins differ greatly in size. The largest known veins are at Rosiclare, where three exceptionally large veins were mined. One vein there was mined for 5,700 feet $(1,740 \mathrm{~m})$ along the strike, more than 900 feet $(275 \mathrm{~m})$ downdip, and to as much as 45 feet $(14 \mathrm{~m})$ in width (Grogan and Bradbury, 1968). More generally the ore shoots in the veins are 300 feet $(100 \mathrm{~m})$ long, $100-200$ feet $(30-60 \mathrm{~m}) \mathrm{high}$, and several feet wide. Throughout the area the largest veins are where the major northeast-trending fault zones change strike or branch. These places, characterized by many faults, are considered promising for future exploration.

\section{BEDDED DEPOSITS}

Bedded deposits have been extensively worked for about 40 years and are known chiefly in two areas: (1) the Cave in Rock district, Illinois, and (2) near Carrsville and Joy, Ky. Bedded deposits have also been found next to some of the veins.

The bedded deposits in the Cave in Rock district are large and have been continuously mined since the 1930's. They are in a horst southeast of the Rock Creek graben and lie in a belt parallel to the side of the graben on the northeast side of the arch. The belt is about 1 mile $(1.5 \mathrm{~km})$ wide and at least 6 miles $(10 \mathrm{~km})$ long; the downdip (northeast) end has not been reached, and the updip (southwest) end, where the belt crosses the axis of the arch, is eroded. The deposits were found where the belt crops out, northwest of Cave in Rock, and they were followed downdip by churn drilling. Exploration for the belt down the dip of the beds has not exceeded a depth of 1,200 feet $(370 \mathrm{~m})$.

The structure and shape of the bedded deposits were illustrated by Weller, Grogan, and Tippie (1952), Brecke (1962), and Grogan and Bradbury (1968). In general the 
deposits have the shape of very long lenses; they are several times as long as they are wide and several times as wide as they are thick. The stratigraphic position of the major deposits is shown in figure 4. They are all in oolitic limestone, and the larger ones are in the Sub-Rosiclare ore zone or below the base of the Rosiclare or Bethel Sandstone. These sandstones each contain a thin shale at the base.

Mapping by this author of the structure and mineral distribution in several ore bodies has shown that the bedded deposits are zoned. Each bedded deposit overlies one or more fissures and is elongate in the direction of the fissure. In some deposits, sphalerite occurs near the fissures or in the central part of the ore body, and barite is more abundant toward the edges and ends of the ore body. In many ore bodies, fluorite occupies a central position and calcite occupies a peripheral position.

The fissures below the Cave in Rock ore bodies are faults of small displacement or joints in well-defined sets which may be marked by steeply dipping veins. Because these fissures occur under the ore bodies and are parallel to the long axes of the ore bodies, the fissures are thought to be the controlling structures through which the ore-bearing solutions reached the favorable beds. Most of the fissures strike northeast, about parallel to the edge of the Rock Creek graben, and they probably formed at the same time as the faults between the horsts and grabens and by the same means. The author believes that fissures of a similar nature may occur in many places bordering the major faults that bound the grabens. Thus, the structural setting of the very productive Cave in Rock district may well be duplicated in belts about 1 or 2 miles $(1.6$ or $3.2 \mathrm{~km})$ wide along the edges of the horsts beside the grabens. Such belts of bordering fissures may occure in areas that total more than 200 square miles $\left(518 \mathrm{~km}^{2}\right)$. In addition, similar structural settings probably occur in the grabens as well as in the horsts, but the grabens have not been explored at all for bedded deposits.

\section{SOLUTION-SLUMP BRECCIAS}

In the 1960's several bodies of mineralized breccia were found associated with bedded deposits in the Cave in Rock district. The largest bodies are in the Hill and North Green mines. Smaller bodies of similar breccia are known in other mines. The breccias do not extend to the surface; they are of solution and slump origin, and their lower limits are not known. Some breccias are potentially large ore bodies, though of low grade.

Figure 5 is a map of one of the larger bodies of breccia found in the Hill mine. This large body of breccia is along and between two fissure zones which strike northeast and dip steeply. The beds bend down progressively from

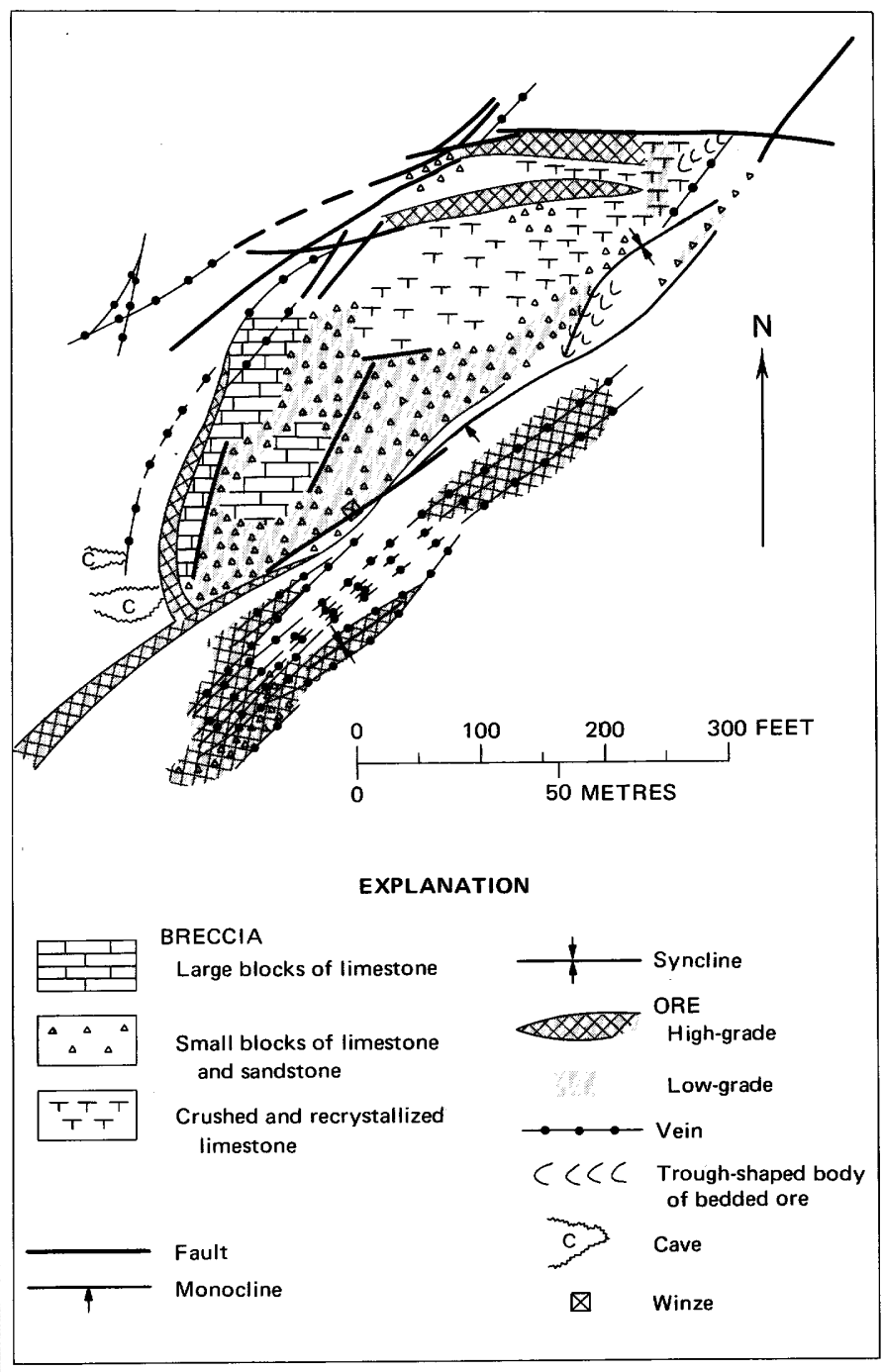

F IGURE 5.-Mineralized breccia of solution-slump origin; Hill mine (1, fig. 2), Cave in Rock district, Illinois.

southwest to northeast toward the breccia and finally are broken and collapsed. All rocks are below their normal stratigraphic position. Blocks from the upper part of the Renault Formation are now well below the position of the Rosiclare Sandstone Member outside the solution-slump structure.

Toward the edges of the slumped area huge blocks of limestone are bounded by faults or veins; toward the center the blocks are somewhat smaller and are separated by strands of breccia that consist of sandstone fragments as much as 3 inches $(8 \mathrm{~cm})$ across and pieces of clay or shale. Finely brecciated limestone is rare in the central part of the body. The largest blocks of limestone in the central part are scarcely tilted; they apparently moved vertically downward. Finer material moved downward into spaces 
between the large blocks. Caves were dissolved in the limestone along the southwest side of the breccia.

The fine breccia was mineralized throughout; the large blocks of limestone in the central part of the slump-breccia contain ore along their edges. The clay and sandstone breccia between the blocks in the central area is filled with fluorite and is low-grade ore. Many of the large blocks surrounding the central area are separated by wide streaks of high-grade ore, and some of these blocks contain pods of ore. Sphalerite and galena are more abundant in this outer part than in other places.

The vertical extent of the breccia is not fully known, but it exceeds 250 feet $(75 \mathrm{~m})$. The breccia extends upward above the Rosiclare Sandstone Member and includes fragments of limestone from the upper part of the Renault Formation. It extends downward through the Ste. Genevieve Limestone into the St. Louis Limestone.

Abundant stylolites, caves, and small cavities indicate that large amounts of limestone were dissolved. The downward movement of all breccia fragments indicates the breccia is of solution-slump origin and is not a diatreme. Mineralization and slumping were contemporaneous, at least in part (Pinckney and Rye, 1972). Therefore, the breccia in the Hill mine and similar breccias elsewhere are considered to have been major channels for the mineralizing solutions. As such, they may contain large bodies of ore.

\section{DIATREMES}

The exploratory hole that was drilled into the center of Hicks dome encountered mineralized rock from a depth of 1,605 feet $(490 \mathrm{~m})$ to the bottom of the hole at 2,944 feet $(897 \mathrm{~m})$. The chief minerals reported were fluorspar and small amounts of sphalerite and galena (Brown and others, 1954). Trace (1960) reported small but noteworthy amounts of beryllium, niobium, thorium, and rare-earth elements in samples from the exploratory hole. An outcrop of breccia, shown by Baxter and Desborough (1965, pl. 1) in sec. 30 , T. $11 \mathrm{~S}$., R. $8 \mathrm{E}$., near the top of Hicks dome, contains a large amount of jasperiod, which had not been reported previously. These facts are evidence of hydrothermal activity in the central part of the dome. From the data about breccias and from observations in the field, this author thinks that all the central part of Hicks dome, shown as Devonian formations in figure 2, may be a breccia. If it is, the central part of the dome is probably a huge diatreme and merits extensive exploration for mineral deposits.

Baxter and Desborough (1965, fig. 3) listed 10 breccias that may be diatremes. Very little is known about these breccias, but, in view of the mineral content of the breccia found in the Hamp drill hole, they should be considered as potential sources of base metals and fluorite and as possible sources of other metals, including niobium.

\section{DEPOSITS CONTAINING CHIEFLY LEAD OR ZINC}

A few deposits have been worked chiefly for lead or zinc and contain little fluorspar. Examples are deposits at the Old Jim mine (Ulrich and Smith, 1905, p. 176-180), the Hutson mine (Oesterling, 1952), the Patrick mine (Weller and others, 1952, p. 130), and the Hickory Cane mine (Trace, 1954, p. 53). The Old Jim, Hutson, and Hickory Cane deposits are veins of high-grade zinc ore; some ore was oxidized to smithsonite. The Hutson deposit also contained several bodies of replacement ore. According to Osterling (1952), replacement ore at the Hutson mine was largely along tension fractures that connect two parallel fissure veins. The replacement bodies were fairly large, massive, and high grade. They contained about 25 percent zinc, but very little lead or fluorite.

A moderately large deposit at the Patrick mine near Cave in Rock consisted chiefly of galena and cerussite and contained only a little fluorite or zinc. The ore was in replacement bodies and narrow veins in the St. Louis Limestone (Weller and others, 1952, p. 130) and was mined from an open pit.

\section{AREA OF MINERAL POTENTIAL}

The area in which mineral deposits have been found and mined is very large and it has been only superficially explored. Reasonable projections indicate that the area of potential production is more than twice as large as the area of known production.

The incentive to explore for new deposits was low during the 1950's and 1960's. Exploration lagged because of the low price of fluorspar and the abundance of fluorspar from foreign sources. With the rise in the price of fluorspar during the last few years, exploration activity has increased. Even so, only a small part of the area having production potential has been thoroughly explored.

Most exploration has been limited to fairly shallow depths. The bedded deposits in the Cave in Rock district have been followed downdip by mining and drilling to a depth of only 1,200 feet $(370 \mathrm{~m})$. The large veins near Rosiclare, along the southeast side of the Carrsville graben, were explored to a depth of more than 900 feet ( $275 \mathrm{~m}$ ) north of the Ohio River, but very little is known of the same structures south of the river. Exploration conducted south of the Ohio River found bedded deposits along the southeast side of the Carrsville graben, where the structural setting is probably similar to that of the bedded deposits near Cave in Rock. Nearly all the old mining centers have been partly explored in recent years by diamond drilling, and the success of such exploration is reflected partly in increased production. 
The major ore control of deposits in the bedded, vein, and solution-slump structures is the intersection of fissures with the Ste. Genevieve and Renault Formations. These formations crop out throughout much of the axial part of the arch in the area shown in figure 2 as older Mississippian rocks. Indeed, the mining area and the outcrop area of these beds largely coincide. These beds extend downdip off the arch into the adjacent basins. Between the north edge of the Cretaceous and Tertiary sediments and the Mississippian-Pennsylvanian contact, these beds underlie an area of more than 1,100 square miles $\left(2,800 \mathrm{~km}^{2}\right)$, and, of course, they extend at depth beyond the Pennsylvanian contact. The depth to the base of the Bethel Sandstone at the outer edge of this area is approximately the thickness of the Chesterian Series, which is about 1,200 feet $(360 \mathrm{~m})$ in most places. Within this area the length of intersections of fissures and favorable beds is hundreds of miles and the intersections extend beyond the area.

The outermost extent of mineralization is not known. The areas in which all mines and prospects are located are shown within the dashed lines in figure 2 . However, Trace and Palmer (1971) reported the occurrence of sphalerite disseminated in siderite east of the Mississippian-Pennsylvanian contact. The minerals are in the Caseyville Formation of Pennsylvanian age, within the Shady Grove graben. Obviously, the dashed lines in figure 2 do not show the limits of mineralization. Instead, the position of lines is based on the faults and the outcrop pattern of the favorable beds.

\section{CONCLUSIONS}

The Illinois-Kentucky mining area probably will continue to be the major source of domestic fluorspar and a small but important source of lead, zinc, and cadmium for many years. Mining operations, on a long and sustained basis, can expect to recover about 9.9 tons, or more, of lead and about 55 tons of zinc for each 1,000 tons of calcium fluoride produced, as well as small amounts of silver, germanium, and cadmium. Barite has potential value, but only a little of it is recovered now. Some deposits contain strontium, chiefly in strontianite, but little use exists now for this metal.

Most ore has come from veins and bedded deposits, and deposits of these types will continue to be important. The veins are along known fault zones that are well shown on existing geologic maps. Additional ore can be found by thorough exploration of those parts of the fault zones where one or both walls are the productive beds. The intersections of faults and favorable beds are unexplored throughout many miles of their length. The large known bedded deposits are in horst blocks beside grabens, and many hundreds of miles of this favorable setting are unexplored. Similar structural settings in the grabens also remain unexplored. More deposits in solution-slump structures may be found associated with bedded deposits. The diatremes are especially intriguing, inasmuch as they may contain large deposits at depth. Some of these structures can be seen on the surface and followed downward. All the known diatremes are in the vicinity of Hicks dome. A search for other diatremes around the dome and exploration of the known ones seems worthwhile.

The intersection of fault zones with certain beds below the Bethel Sandstone is the most important structural ore control and extends throughout most of the entire region. Erosion has removed these beds in only a few small areas. Many places within the mining area where this relation is present are still unexplored. This structural relation also extends down the flanks of the arch, under the area shown in figure 2 as Upper Mississippian rocks. This additional area, if extended out only to the base of the Pennsylvanian beds, is approximately as large as the known mining area.

The Illinois-Kentucky mining area has yielded a substantial amount of fluorspar, lead, zinc, silver, and cadmium for many years. Some of the barite present is now also being recovered. The ore deposits are moderately large and of good grade. The known area of mineral potential can be considerably expanded, and the newly recognized diatreme deposits should be thoroughly explored. In short, the mineral potential of the region is considered to be very large.

\section{REFERENCES}

Bastin, E. S., 1931, The fluorspar deposits of Hardin and Pope Counties, Illinois: Illinois Geol. Survey Bull. 58, 116 p.

Baxter, J. W., and Desborough, G. A., 1965, Areal geology of the Illinois fluorspar district, Pt. 2-Karbers Ridge and Rosiclare quadrangles: Illinois Geol. Survey Circ. 385, 40 p.

Baxter, J. W., Desborough, G. A., and Shaw, C. W., 1967, Areal geology of the Illinois fluorspar district, Pt. 3-Herod and Shetlerville quadrangles: Illinois Geol. Survey Circ. 413, $41 \mathrm{p}$.

Bayley, R. W., and Muehlberger, W. R., compilers, 1968, Basement rock map of the United States, exclusive of Alaska and Hawaii: Washington, D. C., U.S. Geol. Survey, 2 sheets.

Bradbury, J. C., Finger, G. C., and Majors, R. L., 1968, Fluorspar in Illinois: Illinois Geol. Survey Circ. 420, 64 p.

Brecke, E. A., 1962, Ore genesis of the Cave-In-Rock Fluorspar District, Hardin County, Illinois: Econ. Geology, v. 57, p. 499-535.

Brown, J. S., Emery, J. A., and Meyer, P. A., Jr., 1954, Explosion pipe in test well on Hicks dome, Hardin County, Illinois: Econ. Geology, v. 49 , p. $891-902$.

Butts, Charles, 1925, Geology and mineral resources of the EqualityShawneetown area (parts of Galletin and Saline Counties): Illinois Geol. Survey Bull. 47, 76 p.

Clegg, K. E., and Bradbury, J. C., 1956, Igneous intrusive rocks in Illinois and their economic significance: Illinois Geol. Survey Rept. Inv. $197,19 \mathrm{p}$.

Desborough, G. A., 1961, Geology of the Pomona quadrangle, Illinois: Illinois Geol. Survey Circ. 320, 16 p. 
Fraunfelter, George, and Utgaard, John, 1973, Depositional environments-Ste. Genevieve and Chester carbonates and mudstones, south-central Illinois, in Ethridge, F. G., Fraunfelter, George, and Utgaard, John, eds., Depositional environments of selected Lower Pennsylvanian and Upper Mississippian sequences of southern Illinois: Tri-State field conference, 37th annual, p. 158.

Grogan, R. M., and Bradbury, J. C., 1968, Fluorite-zinc-lead deposits of the Illinois-Kentucky mining district, in Ridge, J. D., ed., Ore deposits of the United States, 1933-1967. (Graton-Sales Volume), V. 1: New York, Am. Inst. Mining, Metall., and Petroleum Engineers, p. $370-399$.

Heyl, A. V., Jr., and Brock, M. R., 1961, Structural framework of the Illinois-Kentucky mining district and its relation to mineral deposits, in Short papers in the geologic and hydrologic sciences: U.S. Geol. Survey Prof. Paper $424-D$, p. D3 - D6.

Hook, J. W., 1974, Structure of the fault systems in the Illinois-Kentucky fluorspar district, in Symposium on the geology of fluorsparForum on the Geology of Industrial Metals, 9th, Proc.: Kentucky Geol. Survey, ser. 10, Spec. Pub. 22, p. $77-86$.

Klein, G. D., 1974, Estimating water depths from analysis of barrier island and deltaic sedimentary sequences: Geology, v. 2, p. $409-412$.

McGinnis, L. D., and Bradbury, J. C., 1964, Aeromagnetic study of the Hardin County area, Illinois: Illinois Geol. Survey Circ. 363, 12 p.

Moodie, F. B., III, and McGrain, Preston, 1974, The Eagle-Babb-Barnes fluorspar project, Crittenden County, Kentucky, in Symposium on the geology of fluorspar-Forum on the Geology of Industrial Metals, 9th, Proc.: Kentucky Geol. Survey, ser. 10, Spec. Pub. 22, p. $96-107$.
Oesterling, W. A., 1952, Geologic and economic significance of the Hutson zinc mine, Salem, Kentucky-Its relation to the Illinois-Kentucky fluorspar district: Econ. Geology, v. 47, p. 316-338.

Pinckney, D. M., and Rye, R. O., 1972, Variation of $0^{18} / 0^{16}, \mathrm{C}^{13} / \mathrm{C}^{12}$, texture, and mineralogy in altered limestone in the Hill mine, Cavein-Rock district, Illinois: Econ. Geology, v. 67, no. 1, p. 1-18.

Trace, R. D., 1954, Central part of the Commodore fault system, Crittenden County, in Pt. 2 of Fluorspar deposits in western Kentucky: U.S. Geol. Survey Bull. 1012- C, p. 39-57.

1960, Significance of unusual mineral occurrence at Hicks dome, Hardin County, Illinois, in Short paper in the geological sciences: U.S. Geol. Survey Prof. Paper 400-B, p. B63-B64.

1974, Illinois-Kentucky fluorspar district, in Symposium on the geology of fluorspar-Forum on the Geology of Industrial Metals, 9th, Proc.: Kentucky Geol. Survey, ser. 10, Spec. Pub. 22, p. $58-76$.

Trace, R. D., and Kehn, T. M., 1968, Geologic map of the Olney quadrangle, Caldwell and Hopkins Counties, Kentucky: U.S. Geol. Survey Geol. Quad. Map GQ-742.

Trace, R. D., and Palmer, J. E., 1971, Geologic map of the Shady Grove quadrangle, Crittenden and Caldwell Counties, Kentucky: U.S. Geol. Survey Geol. Quad. Map GQ-880.

Ulrich, E. O., and Smith, W. S. T., 1905, The lead, zinc, and fluorspar deposits of western Kentucky: U.S. Geol. Survey Prof. Paper 36, $281 \mathrm{p}$.

Weller, J. M., Grogan, R. M., and Tippie, F. E., 1952, Geology of the fluorspar deposits of Illinois: Illinois Geol. Survey Bull. 76, 147 p. 
